\title{
The end of leadership?: The shift of power in local congregations
}

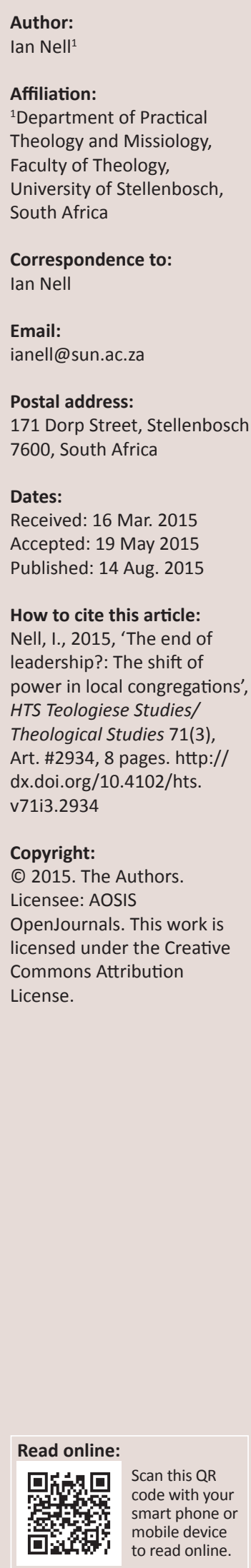

In a qualitative study recently carried out by the author amongst ministers in a Circuit of Dutch Reformed Congregations in a suburban context in the Western Cape, South Africa, respondents were asked whether they sensed a 'shift of view' concerning the role of leadership during the past 20 years in their respective congregations. The research results paint a picture of 'the end of leadership' at least in some form. One can also sense a 'shift of power' over the past two decades in these local congregations, indicating the changing dynamics of leadership. There seems to be a shift of power from the individual leader to the team, the group and the network. The aim of this paper is, firstly, to present some of the empirical results and then to reflect on the underlying reasons for this shift of power by giving a description of some broader philosophical and sociological perspectives influencing this state of affairs. This will be followed by a description of, and reflection on, theological developments on the Trinity and power that might help to understand the 'end of leadership' in some ways. The paper concludes with some thoughts on the role of power and leadership processes at work in local faith communities.

\section{Introduction}

In the first issue of the Mail and Guardian of 2015, Peter Vale wrote an interesting article with the title 'Wanted: Leaders to heal SA'. The article was insightful in two ways. The first is that, according to Vale's perspective, we are currently experiencing the 'end of leadership' within the political arena in South Africa. He illustrates how, two decades ago, one could recall quite a number of names if asked about potential leaders that could lead the country. Some of these people include Thabo Mbeki, Chris Hani, Cyril Ramaphosa and Tokyo Sexwale, to name but a few. In trying to come up with a similar list for the present time, hardly anyone comes to mind.

In interviews that Vale did with a number of people during the festive season, most people could not mention any international leaders that were an inspiration to them. He writes:

Several people I asked simply refused to play this parlour game, saying that the next generation of South

African leaders were keeping their heads below the parapet for fear of losing them. (Vale 2015:2)

In a certain sense, one could point to the fact that this again signals 'the end of leadership'.

The second insight from the article is that it surprises Vale that, in his enquiry about possible international leaders, the name of the current Pope was not mentioned by any of the people that he interviewed. He is convinced that age and experience are not necessarily prerequisites for leadership and refers to the example of the 26-year old Chilean student leader, Camila Vallejo, who played an enormous role in the politics of her home country. He then continues to reflect on the Pope as a global leader and writes:

One global leader who has had the courage to challenge the way in which our world is structured is Pope Francis. In a very bleak age, the pontiff - who was not mentioned by anyone I questioned over Christmas is turning out to be an inspirational leader. (Vale 2015:3)

Vale (2015:3) refers to the way in which the Pope is exemplary in that he does not hesitate to speak the truth to power and purposefully avoids the 'ostentatious trappings of his high office'. What the Pope would like to see, according to him, is that there must be a concerted effort regarding the plight of the poor through an attitude of service. Even in this regard, one can sense the end of a certain form of leadership within the Catholic Church.

In another recent article by the new editor of Die Kerkbode, ${ }^{1}$ Neels Jackson (2014) reflects on leadership in the editor's column and writes:

'n Reaksie op iets wat verkeerd is, kan so maklik 'n oorreaksie word. Miskien moet ons in die NG Kerk onsself afvra of die Reformasie se reaksie op die pouslike outokrasie en wanpraktyke 500 jaar gelede nie 'n oorreaksie geword het nie. (p. 8) 
He goes on to ask whether people in the Reformed tradition are not perhaps thinking and reflecting too little about leadership. ${ }^{2}$ According to him, the alternative to autocratic leadership cannot be the absence of leadership. It is quite clear that processes of leadership continue and often take on different and sometimes surprising forms, calling for a variety of ways in which to study and analyse them. Once again, one could sense in the comments of Jackson the 'end of some form of leadership'.

In light of the above comments, the purpose of this contribution is to attend to the question in the title of the article, namely whether we can indeed speak of 'the end of leadership'. If so, in what way does it relate to the shift of power in local congregations? The structure of the argument in the article will be as follows: Firstly, some attention will be given to the research methodology and the empirical data that were gathered through a qualitative analysis within the Dutch Reformed Circuit of Durbanville. Secondly, the data will be interpreted by making use of different hermeneutical lenses to see what I can find in the literature that will help me to come to a better understanding of this shift in power (if any). Thirdly, the role of and the relation between the Trinity and power will be considered as part of a more normative reflection on possible shifts that might have taken place. Lastly, some thoughts will be shared on the role and power of leadership in local faith communities.

\section{Research methodology}

The research design for the empirical research that I used operates from an interpretive perspective in qualitative research with its roots in hermeneutics as the study of the theory and practice of interpretation (Henning, Van Rensburg \& Smit 2004:19-21). The aim of this kind of empirical research is to provide contextually valid descriptions and interpretations of human actions, which are based on an insider's perspective of people and their world. The research was done by means of a semi-structured interview schedule (six questions) with a sample of leaders in a specific suburban circuit of faith communities where they exercise different leadership functions.

As part of the questions, I asked the interviewees to describe and tell stories in what Henning et al. (2004:53) call '... someone's narrative version of her lived experience (as in the phenomenological interview)'. Semi-structured interviews, allowing openness for narrative and lived experience, still need interpretation to make sense of the data. I selected the Durbanville Circuit of the Dutch Reformed Church as a sample ${ }^{3}$ because the Circuit functions within the northern

2.For some important recent publications within the Dutch Reformed Church on leadership, see the work of Niemandt (2012) and Cordier (2014)

3.'Sampling is the process of choosing actual data sources from a larger set of possibilities. This overall process actually consists of two related elements: (1) defining the full set of possible data sources - which is generally termed the population, and (2) selecting a specific sample of data sources from that the population, and (2) selecting a specific sample of data sources from that qualitative and quantitative research, because it is nearly always necessary to work qualitative and quantitative research, because it is nearly always necessary to work
with a sample of data sources rather than attempting to collect data from the entire population' (Denzin \& Lincoln 2011:799). suburbs of the Cape Town Metropole and in that sense represents one form of an urban lifestyle. Another reason for choosing this specific Circuit relates to the fact that I served as minister in a congregation in this area for ten years. I therefore, in some ways, do have somewhat of an insider's perspective on the activities of the ministers in this area.

The Circuit consists of 10 congregations with more or less 28000 members, making it the biggest Circuit of the Dutch Reformed Church in South Africa. At the moment, 28 full-time ministers are serving the ten congregations, with another five youth workers employed by some of the congregations. The population ${ }^{4}$ of ministers is thus 28. After receiving ethical clearance from Stellenbosch University's ethical committee, I sent a questionnaire via email to each of the ministers. The questionnaire explained the reason for the research and asked six questions. ${ }^{5}$ After two weeks, I received 15 responses with a 'thick description' ${ }^{6}$ of their experiences, making it a very comprehensive data set. For the sake of anonymity, I numbered the answers in the chronological order that I received the responses, and for the analysis, I shall also use this number to refer to them. One of the results of doing this kind of analysis is what scholars call the eventual 'saturation'7 of the data.

\section{Empirical results and organising the data}

The richness of the data and the amount of information that I received makes it impossible to attend to the answers to all six questions in one paper. In this paper, I shall therefore

4.'A group of persons (or institutions, events, or other subjects of study) that one wants to describe or about which one wants to generalize. In order to generalize about a population, one often studies $a *$ sample that is meant to be representative of the population. Also called $*$ target population and 'universe' (Denzin \& Lincoln 2011:240).

5.The six questions were the following: 1 . If, in a figurative sense, you get out onto the 'balcony' challenges that your ministry faced and that made an impact on your ministry? 2. Scholars distinguish between task leadership (pastoral care, preaching, teaching et cetera), transactional leadership (management and administration) and et cetera), transactional leadership (management and administration) and transformational leadership (changing the culture of a congregation). Which of
these three took up the most of your time over the past years and what are the these three took up the most of your time over the past years and what are the
reasons? 3. Do you think that, during the past 20 years, there was a shift in the way people perceive the 'offices' (deacon, elder and minister)? If so, what are the reasons for this shift? 4. Leadership frequently focuses on 'technical changes' (with the focus on tasks, roles and structures) and 'adaptive changes' (with the focus on the system and culture of a congregation). What were the technical and adaptive changes that your congregation experienced over the past 20 years? 5. At the last General Synod, the DRC accepted a document on 'the missional nature and calling General Synod, the DRC accepted a document on 'the missional nature and calling of the church'. How do you understand this missional nature within your ministeria context, and how do you think it influences your ministerial praxis? 6. What do you see, from the 'balcony', to be the challenges for your ministry during the next 20
years?

6.'Most efforts to define it emphasize that thick description is not simply a matter of amassing relevant detail. Rather, to thickly describe social action is actually to begin to interpret it by recording the circumstances, meanings, intentions, strategies, motivations, and so on, that characterizes a particular episode. It is this interpretive characteristic of description rather than detail per se that makes it thick' (Denzin \& Lincoln 2011:297).

7.'Saturation is the point in data collection when no new or relevant information emerges with respect to the newly constructed theory. Hence, a researcher looks at this as the point at which no more data needs to be collected ... Some researchers consider a sample size of 15 to 20 as appropriate for saturation of themes durin consider a sample size of 15 to 20 as appropiate for saturation of themes during analysis; however, the sample size will vary depending on the context and conten under study. Researchers also note that saturation cannot be achieved through frequency counts but instead must be achieved through an examination of the variations within the data and how these variations might be explained in the context of the emerging theory. Therefore, it is essential at the early stages of analysis to consider each piece of data equally because this allows researchers to locate, understand, and explain variations within the sample' (Denzin \& Lincoln 2011:192). 
only concentrate on the third question and its answers to see what can be learnt about the shift in the way in which people perceive the offices that are operative in the different faith communities to which I referred in the introduction. I do this with the intention of finding some initial answers as a response to the basic research question of the study.

Question 3: Do you think that, during the past 2 years, there was a shift in the way in which people perceive the 'offices' (deacon, elder and minister - thus, the leadership)? If so, what are the reasons for this shift?

The first thing that surfaces when one starts to interpret the data is that all of the respondents agreed that they could definitely sense a shift over the past 20 years, and most of them started their answers with the affirmation 'for sure'. After the initial scanning of the data, it became necessary to categorise the data by making use of codes and families. I decided firstly to look at some of the images, metaphors and models that a number of the respondents used to describe the shifts that they registered. After naming some of the images and metaphors, I try to discuss the underlying reasons by making use of a number of concepts in the process of categorising.

\section{Images, metaphors and models}

It is interesting to see how some of the respondents described these shifts by making use of models of leadership, for example, by referring to the shepherd and body-of-Christ models whilst some used the images of co-traveller, lowchurch and even friend:

- Respondent 1: 'The initial response 20 years ago in the Dutch Reformed Church was built mainly on the assumption that the traditional church functioned according to the shepherd model. Against this model, the so-called body-of-Christ model developed with a shift that accompanied the way in which the offices were perceived. Mega churches in the suburbs were, for practical reasons, not well fitted to use the shepherd model, and this gave a huge impetus for the shift towards the body-of-Christ model.'

- Respondent 6: 'I am convinced that a definite change in perception took place. We moved more and more towards what one can call a "low-church" view of the office. The notion that a person is set aside for a specific office and that the special offices in some way or another are set apart for specific people and being respected for that completely disappeared. I think the more egalitarian and genial culture played a significant role in this regard. People rather want to see the minister as a friend and do not want to experience the traditional "distance" caused by the formal clothing et cetera that was the case in the past.'

\section{Underlying reasons}

From the images, metaphors and models, it is already clear that an enormous shift took place concerning the perceptions of leadership. If one starts to dig deeper into the data, looking for the underlying reasons given by the respondents, the following are some of the most important responses one finds in the data set.

\section{Historical reasons}

The role that the development of the view of the offices played during the time of the Reformation and in the centuries after that were often referred to in the data. Some of the following responses illustrate the point:

- Respondent 2: 'I am careful about an exaggerated and snobbish approach to the offices that is related to academic standards and the use of the prescribed rituals for the worship service. According to me, our view of the Reformed offices developed during the time of the Reformation in opposition to the Roman Catholic Church's view of the sacraments. In the meantime, the ecumenical movement and talks about church unity contributed to the current situation where Reformed people learn from the Catholics about important symbolic practices like baptismal renewal, liturgical calendars, the Church year, lectionaries, liturgical colours and candles, the Holy Week, et cetera.'

\section{Urbanisation}

There is little doubt that the urbanisation of members of the Dutch Reformed Church during the past century had an enormous impact on the role of leadership, as is evident from the following response:

- Respondent 1: 'Historically, the members of the Dutch Reformed Church were rural people who socialised in this way, and that contributed towards a shepherd model for the ministry - the pastor knowing each and every one. As urbanisation took place, the phenomenon of the city and the suburban life started to gain prominence. Many congregations were founded in the suburbs, and many more developed because of secession [afstigting] as the model for growth.'

\section{The rise of mega churches and specialisation}

It is quite evident that the previous reasons directly relate to further developments in the form of mega churches and specialisation:

- Respondent 1: 'The rise of the mega-church concept in the USA during the 1970s was a great inspiration for a similar development in South Africa. A few reasons can be mentioned: (1) the rise of the charismatic movement with big groups gathering around a leader; (2) an acceleration in the way in which people could relate to big institutions, public spaces and venues; (3) the realisation that this structural revolution was not necessarily accompanied by a cultural revolution. The reason for this is that mega churches were in many ways still very rural in culture, and many members quite often expressed their need for the shepherd model (personal attention and house visitation).' 


\section{Cultural changes and a diminished view of the offices}

Some of the cultural changes already became apparent in the previous responses, but that they are directly related to a diminution in view of the offices is very evident from the following responses:

- Respondent 3: 'At the level of the congregation, the public importance of the office diminished considerably. Our the different offices to adapt to the new circumstances. This is also the biggest reason for the cultural changes. People have become more individualistic, have less time for church activities and choose to spend their energy on relationships rather than on the institution. In this regard, the view of the role of the minister has also changed, specifically in the age group under 45 . In the congregation, he or she is seen as an ordinary human being, having to perform different tasks coming from an archaic tradition.'

- Respondent 10: 'People's lives are increasingly individualistic, and they do not easily allow others into their "personal spaces". Usually ministers and elders are not allowed in, and if at all, only in times of crisis. For Scriptural knowledge, they use the Internet or people who write books and conduct seminars, or they watch TV shows and then make their own decisions regarding questions of faith, et cetera.'

- Respondent 11: 'The view of the offices has changed for sure - it is not so important anymore to serve on the Church Council or even to have a Church Council. I think it relates to the fact that people are not as interested in structures functioning from the top anymore, being much more interested in flat structures.'

\section{Technological and security reasons}

An interesting response relates to aspects concerning the security of members and the use of technology:

- Respondent 12: 'Because of crime and the streets no longer being safe, members make use of technology. Webpages, electronic information and Facebook pages are becoming more important to spread information, but the use of these media also ask some adaptation from congregational leadership. To gain entry into the residences of members is a problem. High security fences and personal safety are priorities for people, and one has to work smarter to gain physical entrance into where people are staying.'

\section{Reasons related to different generations}

It is very insightful to find amongst the responses of the younger ministers deliberate reflections on the fact that they are from a younger generation. One example suffices:

- Respondent 13: 'It strikes me that, specifically regarding the 20-35 age group, you occasionally find that they are not consciously aware of the denomination to which they belong. They participate and feel a sense of belonging because of a sense of authenticity that they experience and the fact that they find some kind of "connection" with fellow believers, flowing spontaneously from "community". If you start talking to them about membership and completing forms, they become suspicious. "What do you want to do with this?" is normally their question. Even where they are involved in small groups and serving in different ways, they are "officially" nowhere in the books, which is very difficult for the personnel in the church office.'

\section{Theological reasons}

In the responses under the heading 'Images, metaphors and models', many of the images and metaphors that have deep theological roots were mentioned, and these will not be repeated here. However, what is of interest here is to see the significant role that the 'priesthood of all believers' is playing in the responses:

- Respondent 6: 'There is much more emphasis on the priesthood of all believers and the congregation as the body-of-Christ where members have the opportunity to use their gifts and to play different roles. I do, however, think that the more egalitarian and genial culture also plays a role here. People rather want to see the minister as a friend and do not want to experience the traditional "distance" caused by the formal clothing et cetera as was the case in the past. It does have certain advantages but definitely also a down-side - you do have to "earn" your place in the lives of people rather than rely on your office. The danger that issues like personality, popularity, et cetera can play too big a role, specifically concerning the office of the ministry, looms very large.'

\section{Interpretation of the data through the lens of power}

One could use a number of possible lenses to interpret the data to come to a better understanding of the shift in perspective that took place during the last 20 years concerning leadership and the different offices in ministry. The focus of this article is on the role of power and how this notion helps us to understand this shift. This happens within the South African context with specific cultural factors playing a role. Therefore, special attention needs to be given to the influence of power in the history of the Church and specifically in the relationship between the Dutch Reformed Church and the state in the previous political dispensation.

According to Lalloo (1998:39, 43-44), a reciprocal relation between the Dutch Reformed Church and the state can being traced way back in history to the relationships with the Dutch and the British governments in previous centuries. During the 20th century and the era of Afrikaner Nationalism, the Dutch Reformed Church played a central role in the process of the development of Afrikaner identity and, specifically, nationalism. The close relationship between the Dutch Reformed Church and Afrikaner nationalism is well illustrated in the theological founding formulated by the Dutch Reformed Church on which nationalism thrived. In this way, Afrikaner churches played a significant role in legitimising the policies of the National Party for separate development: 'It was to certain Afrikaner theologians that 
the National Party ideologists turned for scriptural and theological justification for their racial policies and too readily obtained them' (De Gruchy in Lalloo 1998:43).

Although it might be difficult to quantify the degree to which the Dutch Reformed Church and the National Party reciprocally influenced each other as well as the role that the ministers played and their power in all of this during the years of apartheid, it is helpful to take this part of history into consideration when one tries to reflect on the role of authoritarian leadership that was so prevalent during this period. In other words, the power of the clerical leadership and the way in which they used it cannot be over-emphasised.

Power often operated to keep different forms of hierarchy intact and forced itself from above. Theories from the social sciences can be very helpful to understand the dynamics between power and leadership.

The well-known sociological thinker, Max Weber (18641920), did important work concerning classical theorising on power and authority. He theorised that there are three forms of authority: rational-legal authority, traditional authority and charismatic authority (cf. Dreyer 2002:627). He preferred the first type of authority according to which roles and positions can be defined and where authority and power are directly related to these positions and roles. Weber's work contributed towards a theoretical framework within sociology known as the structural-functionalist school of thought. Through the work of scholars like Habermas (1984) and Taylor (2007), this understanding of power and authority later developed into something that is practised from within the role and position that a person plays through the use of organisational and management techniques in view of achieving higher sufficiency. Such an understanding of power does, however, still operate from the assumption of coercion and incentives related to the role or function. According to Van Gelder (2007:2-4), such an understanding of power does not sufficiently take into account the role of power within social relationships and the specific context in which it is embedded. It often leads to power seen as an abstract commodity practiced and used by people in certain positions.

A number of scholars havealready pointed to some problematic presuppositions in Weber's theoretical perspectives on power and not only criticised them but also developed some interesting alternatives. At least three prominent names feature in this regard, and all of these scholars contributed to what later became known as the so-called social-critical theory on power. They were Karl Marx, Friedrich Nietzsche and Michael Foucault ${ }^{8}$. The biggest contribution from Marx came through his insight that the exercising of power is directly related to the economic order of the day, and through that to the bigger social order of society. Nietzsche defined the will to power as the primary human driving force and the basis

8.Foucault does have the reputation as the "philosopher of power' because the idea of power was a central concept in his work, as was the case with his mentor Nietzcshe (Hart 2003:67). for organising the social order. The way in which Foucault saw the relationship between power and knowledge was also very influential in the development of the social-critical theory. ${ }^{9}$ According to him, knowledge is not only power, but the opposite is also true: the exercising of power is part of the process in which human knowledge is constructed (Van Gelder 2007:5-6).

The work of a number of so-called post-structural theorists that operated during the 1960s and that also further developed on the contributions of the previous thinkers paved the way for the development of a comprehensive social-critical theory. This theory makes use of deconstruction to reflect on the role that power is playing within the social order. In this regard, a hermeneutics of suspicion is very helpful to point to the fact that all human knowledge and thinking about the way in which power operates are socially constructed and within a specific historical context. According to Van Gelder (2007:6), these deconstructive and socially constructed approaches ask important questions about the way in which power operates, for example: 'Who is being privileged by this perspective' and 'Who is being marginalised by this perspective?'

It is in line with these thoughts that Robert Greenleaf, the founder of the Greenleaf Centre for Servant Leadership, identified three forms of power: power of coercion, manipulating power and power through persuasion. He argues that, even where power of coercion is used in a sensitive and thoughtful manner, it still has the potential to be harmful and can lead to violence. Unfortunately, we find power of coercion and power through force throughout society, even amongst highly developed and intellectual people. In contrast to power of coercion and manipulative power, Greenleaf (1988:82-85) goes on to describe the role of persuasion. According to him, persuasion is the act in which one person helps another person through the logical organisation of facts to personally give the first step towards a new point of view. It precludes any form of trying to coerce another person into something.

These theoretical perspectives are very helpful in obtaining a better grip on the way in which power and authority are operative within the circles of leadership in faith communities and congregations. What becomes apparent when using these different perspectives as hermeneutical lenses on the data is that one can indeed speak about the end of a specific form of power that became a reality amongst the population that was interviewed. One can sense a purposeful shift away from authoritarian forms of leadership to a more rational-legal understanding in the words of Weber. From a socio-cultural and historical perspective, one can understand that this move directly relates to the way in which many of the members of the Dutch Reformed Church experienced a

9.The central feature of Foucault's (1983:208-226) theoretical thoughts concerning the many faceted cont the many faceted concept of power is that one can see it on the most elementary level as the influence of one person on another. According to him, this influence forms the foundation for all interaction between people on earth. He is convinced that we cannot escape this fact of life, and we do have to make an effort to learn to understand this process. We also have to learn to channel power in a positive way in society. One of Foucault's central assumptions is that power is not in itself good or bad, but neutral. The problem, however, is that it can easily be abused. 
loss concerning political power during the past 20 years. At the same time, one can also sense a form of deconstruction of power (Foucault 1983; Greenleaf 1988) where the power of coercion and force had to make way for the power of persuasion.

The shift one is registering does not exclude the danger that some leaders might from time to time 'default' to exercise power through manipulation and coercion. Within the paradigm of autocratic leadership, it can easily happen that the minister can use the power that has been ascribed to the office in destructive ways, resulting in forms of coercion and manipulation. Wherever power is misused in this way, it causes social hierarchies and, in this case, a hierarchy where the minister does have a higher and more important office than other office bearers in the congregation. ${ }^{10}$ This hierarchical ordering causes social distance between the minister and the rest of the group of leaders and members with the result that some of the members with potential to take the lead in the congregation do not have the confidence to use their talents in service of the congregation.

What is happening here, however, is not unique to this group of respondents. According to the well-known sociologist Castells (2004:425-427), 'power' is in the process of being redefined and renegotiated all over the world. Various shifts are taking place, including shifts from physical power to intellectual power, from guns to information, and so forth. De Gruchy and Ellis (2008:18) are of the opinion that paying attention to power implies that relationship differences should be examined in terms of certain key factors. These differences include race, age, gender, language, nationality and professional status, and each has a unique influence on the exercising of power. The question remains: Do we find any 'theological evidence' for this shift in perspective? This will be the topic of interest in the next section.

\section{Trinity and power}

When we turn to the Scriptures and the Christian tradition for some guidance on the understanding of power, it is very ironic that the primary insight that we find, especially in the New Testament, is the fact that Christian leadership is not in the first place about leadership but about being a follower, known in the Christian narrative as discipleship (Foss 2002:95-100). In the gospels, we read that the Son of God does not call people to lead other people but to follow him (Mt 4:18). Once again, this is an important shift to keep in mind.

Over the past decades, a number of scholars have pointed to this important approach to Christian leadership and the use of power. Maybe one of the most well-known in this regard is the Roman Catholic priest and scholar, Henry Nouwen. He wrote a popular book (1989) on Christian leadership with the title In the name of Jesus: Reflections on Christian leadership. According to him, to be a leader, you must be prepared to give your life to Christ in humble submission by living in prayer and meditation at Jesus' feet (Nouwen 1989:66). He strongly argues that there is always the temptation to try to lead in a spectacular way, but that a Christian leader does have to resist this temptation because it is not in the first place about the leader but about following Jesus Christ (Nouwen 1989:38-39).

It is also in this regard that the insights of Zscheile (2007) helps us to understand the relationship between the Trinity and power and sensitises us for another very important shift in power. For me personally, this may be the most important shift. According to him (Zscheile 2007:43), it was the rediscovery of the doctrine of the Trinity as one of the most important themes in Western theology during the recent decades that highlighted the shift. He is of the opinion that many scholars researched the Trinity from an ecclesiological perspective by looking at the possible implications of the interrelations, but the inferences of these findings for Christianleadership stillneed somemore reflection. According to him, the possibility to reflect on this relationship from a Trinitarian imagination does hold different possibilities.

The argument of Zscheile (2007:47-49) boils down to the fact that single, monarchical, hierarchical and autocratic forms of leadership are increasingly under suspicion in both the church and academy, not to mention the wider public. This is the result of Deistic images of God that eclipsed Trinitarian images of God for a very long time. A Deistic approach quite often leads to distant and monistic images of God, seen by many critics of religion as nothing more than human projection as the philosopher Feuerbach pointed out. Over and against this approach, Trinitarian images of God focus on the perichoresis and the Trinitarian nature of God. This helps to reflect on the God-human interactions in non-hierarchical and egalitarian ways in which community becomes very important.

In the area of leadership, this shift from Deistic to Trinitarian images of God has important implications, for example, the idea of 'diversity-in-unity' (Zscheile 2007:53) resulting in the opportunity of different people with different gifts that can serve the faith community. Arguably, the most important implication is once again the notion of 'cruciform leadership' (Zscheile 2007:54) relating to the incarnation of Christ and what happened on the cross where Christ completely identified with the human condition and emptied Himself from all forms of power (Phlp 2). It is precisely these notions of self-emptying one's own life and identifying with the needs of one's neighbour, many times at great personal cost, that stand in such sharp contrast to current understandings of power and leadership.

Robinson (2008:80-97) convincingly shows how the shift of power also relates to the shift from Christendom to the post-Christendom era. According to him (Robinson 2008:84), the clergy served three roles during the Christendom era: 'chaplain, scholar, and part of the authority structure of the 
town or community'. It is very interesting that the notion of leadership does not even appear on the list. He is, however, convinced that clergy do have to act as leaders in the current context, and that leaders who are in the position to help the faith community need to find and develop their own identity and to address some of the main obstacles and challenges confronting the community. For this reason, they ought to be '... teachers of the faith and ministry mentors' (Robinson 2008:84). Both these roles have the implication that the ministry cannot be dealt with only by the clergy, as was the case in Christendom. It should also be dealt with by the members of the congregation.

\section{Power and leadership in local faith communities}

In this last part of the article, I want to pay attention to some comments on power and leadership in local faith communities with a specific focus on the implications that the shift in leadership powers hold for local congregations. Percy (2010:61) convincingly shows how a proper understanding of the role of power in a local congregation can be used as a hermeneutical key to better understanding the functioning of the local faith community.

Percy (2010:62) is convinced of the fact that the normal way of reflecting on the role of power in congregations is to focus on the misuse or the loss of power. He is, however, of the opinion that there are more important and deeper reasons to focus on power in the local congregation. He describes (Percy 2010:63-64) the following four reasons that might help better to understand the 'end of leadership' and the 'shift in power' that was witnessed in the analysis of the empirical data:

- Firstly, one finds the fact that power is always contested, be it by individuals or through groups in the congregation or by people from outside the inner circle of leadership. Factors like race, class, gender and generation usually play a role in these contestations and quite often lead to conflict.

- Secondly, the conventional ways of understanding power also help to better understand the shifts in power. The theories and insights from scholars like Weber and Foucault are very helpful in this regard, as was seen in the discussion.

- Thirdly, there are also unconventional ways of understanding power. To only concentrate on the offices or on people in formal positions of power in the analysis means paying attention to only half of the challenge concerning power. There are indeed hundreds of different, unofficial and subtle ways in which power is exercised in congregations and which are meaningful for the functioning of communities.

- Fourthly, it is only when you immerse yourself in the local congregation that you start to understand the many different and complex ways in which power is operative in the community. Being a participant observer helps the researcher to develop a deeper literacy for the different ways in which the dynamics of power are at work amongst the people of faith.
As part of the deeper literacy referred to in the previous paragraph, it might be helpful to pay attention to a 'theology of leadership' in our considerations concerning the role of power. In this regard, reflecting on a text like Philippians 2:511 can act as an important '... countercultural interpretation of the dominant discourses within the social definitions of leadership' (Ayers 2006:4). Texts from Scripture and tradition can help us to understand the way in which leadership was exercised in biblical times as well as in the centuries that followed. The way in which Christ embodied leadership through his public ministry and the way in which the disciples and other people followed Him do not only serve as inspiration but also encourage us to become followers ourselves. The act of Jesus's self-emptying (kenosis) helps believers that want to take up positions of leadership to understand the process of self-emptying as something that continues throughout life. It is indeed through emptying ourselves that we are transformed and that it becomes possible for us to serve other people so that they too become followers of Christ (Ayers 2006:5).

\section{Conclusion}

In the introduction to the article, the purpose of the research was formulated as an attempt to pay attention to the question of whether we can speak of the 'end of leadership', and if so, how does it relate to the shift in the power of leadership in the local congregation? The data that were gathered through the empirical research point to the fact that we can indeed speak of the 'end of leadership' in the form of monarchical and hierarchical approaches. In light of the analysis of the data, one can, with a great degree of certainty, declare that there was indeed also a shift in perception concerning leadership in the direction of democratic and egalitarian approaches where the priesthood of all believers and the importance of relationships and networks play an important role.

From the analysis of the data, it becomes evident that the reasons for this shift can be found in a number of factors of which the historical reasons, urbanisation of members, the appearance of macro congregations and specialisation, cultural changes, a diminished view of the offices and theological factors are some of the most important. Theories from social-scientific perspectives and a theology of leadership as hermeneutical aid helped one to gain a deeper understanding of this phenomenon. Reflecting on the data and its interpretation also helped to develop a deeper literacy that will be helpful in nurturing a new generation of church leaders.

\section{Acknowledgements}

\section{Competing interests}

The author declares that he has no financial or personal relationships which may have inappropriately influenced him in writing this article. 


\section{References}

Ayers, M.A., 2006, 'Toward a theology of leadership', Journal of Biblical Perspectives in Leadership 1(1), 3-27.

Castells, M., 2004, The information age: Economy, society and culture, vol. II: The power of identity, 2nd edn., Blackwell Publishing, Oxford.

Cordier, G.S., 2014, 'Kernkapasiteite van die predikant as missionale leier in die vorming van ' $\mathrm{n}$ missionale gemeentekultuur', PhD proefskrif, Departement Missiologie, Universiteit van Pretoria.

De Gruchy, S. \& Ellis, W., 2008, 'Christian leadership in "another country": Contributing to an ethical development agenda in South Africa today', in S. de Gruchy (ed.), From our side: Emerging perspectives on development and ethics, pp. 9-20, Rozenburg Publishers, Amsterdam.

Denzin, N.K. \& Lincoln, Y.S., 2011, The Sage handbook of qualitative research, Sage, London.

Dreyer, Y., 2002, 'Leadership in the world of the Bible: (De)institutionalisation as an ongoing Process', Verbum et Ecclesia 23(3), 625-641. http://dx.doi.org/10.4102/ ve.v23i3.1228

Foss, M.W., 2002, A servant's manual: Christian Leadership for tomorrow, Fortress Press, Minneapolis.

Foucault, M., 1983, 'The subject and power', in H. Dreyfus \& P. Rabinow (eds.), Beyond structuralism and hermeneutics, pp. 208-264, Chicago University Press, Chicago.

Greenleaf, R.K., 1988, The power of servant leadership, Berret-Kohler Publishers, San Francisco.

Habermas, J., 1984. The theory of communicative action, vol. I. Beacon: Boston.

Hart, D.B., 2003, The beauty of the infinite: The aesthetics of Christian truth, Eerdmans, Grand Rapids.
Henning, E., Van Rensburg, W. \& Smit, B., 2004, Finding your way in qualitative research, Van Schaik Publishers, Pretoria.

Jackson, N., 2014, 'Die kerk se leiers', Die Kerbode, 16 Oktober, bl. 9.

Lalloo, K., 1998, 'The church and the state in apartheid South Africa', Contemporary Politics 4(1), 39-55. http://dx.doi.org/10.1080/13569779808449949

Niemandt, C.J.P., 2012, 'Trends in missional ecclesiology', HTS Teologiese Studies/ Theological Studies 68(1), Art. \#1198, 9 pages. http://dx.doi.org/10.4102/hts. v68i1.1198

Nouwen, H., 1989, In the name of Jesus: Reflections on Christian leadership, Darton, Longman \& Todd, London.

Percy, M., 2010, Shaping the church: The promise of implicit theology, Ashgate, London.

Robinson, A., 2008, Changing the conversation: A third way for congregations, Eerdmans, Grand Rapids.

Taylor, C., 2007. A secular age, Cambridge University Press, Cambridge.

Vale, P., 2015, 'Wanted: Leaders to heal SA', Mail \& Guardian, 01 January, viewed 15 January 2015, from http://www.mg.co.za/article/2014-12-30-wanted-leaders-toheal-sa

Van der Borght, E.A.J.G., 2000, Het ambt her-dacht: de gereformeerde ambtstheologie in het licht van het rapport 'Baptism, Eucharist and Ministry (Lima, 1982) van de theologische commissie 'Faith and Order'van de Wereldraad van Kerke, IIMO Research Publication 55, Zoetemeer.

Van Gelder, C., 2007, 'Defining the issues related to power and authority in leadership', Journal of Religious Leadership 6(2), 1-14.

Zscheile, D.J., 2007, 'The Trinity, leadership, and power', Journal of Religious Leadership 6(2), 43-63. 